\title{
環軸椎脱臼における手術成績の検討
}

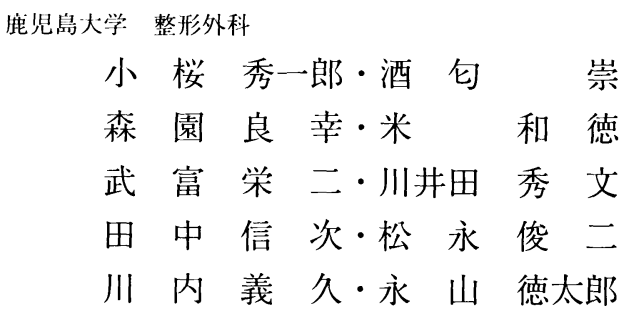

\section{Clinical Study in Operative Results of Atlanto-axial Dislocation}

by
Shuichirou Kozakura, Takashi Sakou, Yoshiyuki Morizono, Kazunori Yone, Eiji Taketomi, Hidefumi Kawaida, Shinji Tanaka, Shunji Matunaga, Yoshihisa Kawauchi and Tokutarou Nagayama

\author{
Department of Orthopedic Surgery, Faculty of Medicine, Kagoshima University, Kagoshima, Japan
}

\begin{abstract}
The operative results were studied on the comparison of the operative procedures in 43 patients with myelopathy due to atlanto-axial dislocation. Transoral anterior fusion was performed in 11 cases, transoral odontoidectomy in 5, McGraw's method in 13 and occipito-cervical fusion with a rectangular rod in 14 . The cause of atlanto-axial dislocation was rheumatoid arthritis in 17, congenital anomaly in 17, trauma in 6 and idiopathic in 3. Occipito-cervical fusion with a rectangular rod was the best procedure for the improvement of the myelopathy. This procedure had a good effect on prevention of postoperative complications such as nonunion. This strong internal fixation allowed early initiation of rehabilitation with only simple cervical splints.
\end{abstract}

\section{はじめに}

環軸椎脱F川は種々の原因にて生ずるが, 脱F丁の程度 が進行すると重篤な脊能道怔状がみられるようになり， 治㙩に難渋することも少なくない，従来，我々は，春 髄症状を合併する環軸椎脱F対して，McGraw 法に よる後方からの環軸椎固分術や, 経口的な環軸椎沽尘 術あるいは蒌突起切除術を行ってきたが, 近年では rectangular rodを併用した後頭頚椎固定術に，必要に 応じて環椎の椎う切除を加えたすう法を用い垦好な成績

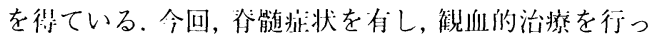
た環軸椎脱臼について, 脊髄症状の改善度を手術方法 別に比較検討した.

\section{対象および方法}

1974 年から 1989 年までに, 当科にて手術を施行し た環軸椎脱FJは 84 例であり, 術前に余髄症状を呈し ていたものは男性 14 例, 女性 29 例の合計 43 例であっ た. 年龄は 10 才〜 82 才で平均 53 才であり，原因疾 患としては，慢性関節リウマチ（以下 RA）が最も多 く 17 例であり, 次いで Os odontoideum 11 例, 外傷 6 例, 特発性 3 例, その他 6 例であった。

手術方法は経口的前力j固走術 11 例, 経口的㐘突起 切除術 5 例，McGraw 法 13 例，rectangular rod を併 用した後頭顏椎田恣術 14 例であり，術後平均経過観 察期閆はそれぞれ 5 年 6 力月，6 年 6 力月， 6 年 3 力 月， 2 年 1 カ月であった。

rectangular rodを用いた spinal instrumentationを 

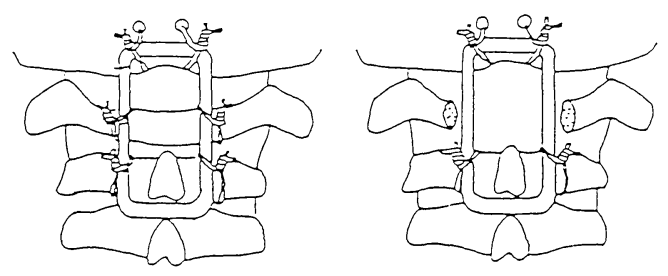

(C1 laminectomy)

図1 rectangular rodを用いたSpinal instrumentationをボす

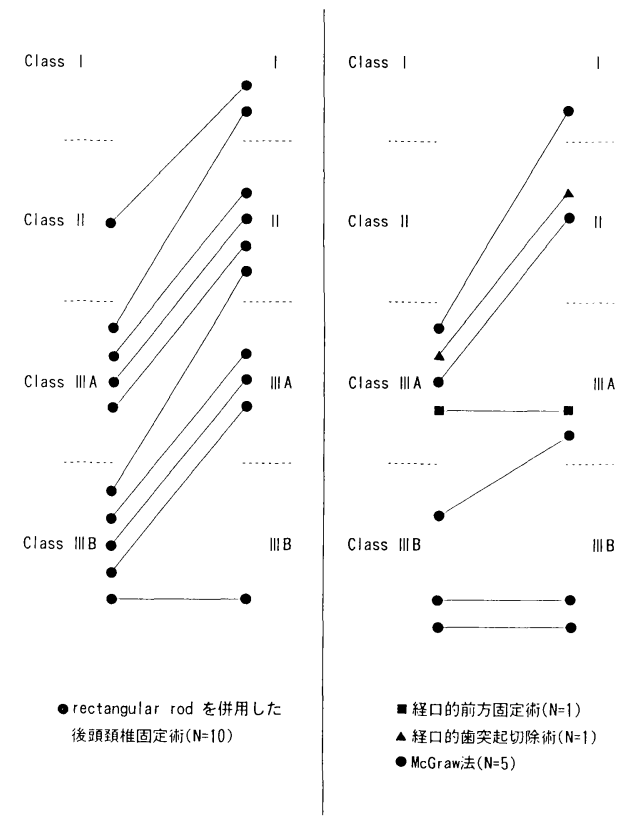

图 $2 \mathrm{R} \mathrm{A}$ 症例での䄃鹃症状の改善度 $(\mathrm{N}=17)$ Ranawat の評価法を用いて判定した

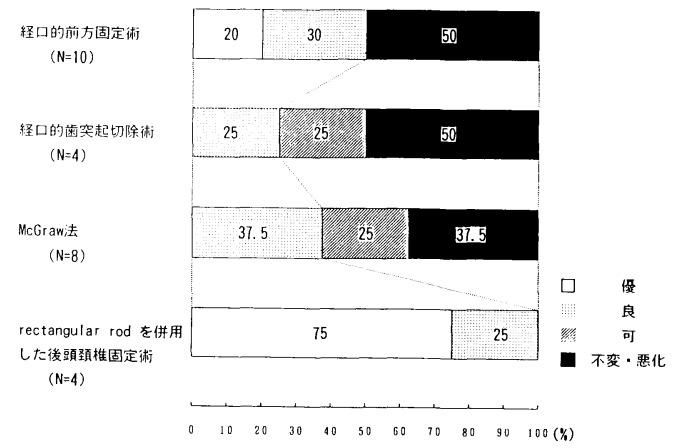

図 3 非 $\mathrm{R} \mathrm{A}$ 症例での命髄症状の改善度 $(\mathrm{N}=26)$ 日本整形外科外会䅡部脊髄症性脊髄症治㙩成績判定 基準を平林の方法にて算出した改善率を用いて判定 した
示す (図 1 ). 固定範乖は, 後頭骨から軸椎までが 10 例, 第 3 澒椎までが 4 例であった。 また，環椎の椎ら切除 を加えたものは 12 例であった.

手術方法別の術後の脊髄症状の改善度を, RA を原 因疾患とするものに対しては Ranawat の評価法にて, その他の疾患を原因とするものに対しては, 日本整形 外科学会澒部脊椎症性脊䯣症治療成績判定基準を平林 の方法にて算出した改善率を用いて判定した.

\section{結果}

RAを原因疾患とする 17 例では, rectangular rod を併用した後頭頝椎固定術で，10 例中 9 例に 1 段階 以上の脊髄症状の改善をみた。一方，他の手術方法群 では， 7 例中 4 例に 1 段階以上の改善をみた（図 2 ).

RA 以外を原因疾患とする 26 例では，優と良を合 わせた有效率は, rectangular rodを併用した後頭澒椎 固定術で $100 \%$ と最も良好な成績を得た。次いで経口 的前方固定術 $50 \%$, McGraw 法 $37.5 \%$, 経口的歯突 起切除術 $25 \%$ の順であった（図 3 ).

rectangular rod を併用した後頭䅡椎固定術は, 最も 術後合併症の発生頻度が低く, 特に偽関節の発生は全 くみられなかった。

\section{考察}

環軸椎脱巨ににける観血的治療の原則は環軸椎部の 固定を行い，金柱の妿定を図ることである，後方から 環軸椎を固定する GallieやMcGraw の法では，環 軸椎の転位が高度で整復が村難な症例では, 宵髄症状 の改善は期待できず，また，内固分わがそしいため再 脱田や偽関節をきたすことも少なくない ${ }^{2)}$. 経口的前 方固定術は, 術前, 術後の管理が煩雑なこと, 感染の 危険性があること, 手術視野が狭いことなどの問題点 がある。

さらに，㝓髄戍状を有し，整復位が得られない为例 などでは，前方あるいは後方からの除坐が必要となる. 椎可切除を行うことは, 支持組織である後方要素を破 壊することにより不姿足性が増強するため，まず前方 固定を行って脊柱の安走性を獲得した後に椎列除を 追加することが必要であるとされている3．また，経 口的歯突起切除術は, 有效なお法であるが, 内固先力 にそしいために術後の厳重な外沽定が必要である11. これに対して，近年，我々が行っている rectangular rodを併用した後頭頚椎固定術は，強力な内固定力を 
有するため, 整復位の保持に優れ, 術後も陑椎カラー などの簡単な外固定を 3 力月程度用いるのみで良好な 骨溇合が得られる。しかも，不安定性を增強させるこ となく, かつ安全に環椎の椎门切除を行い除生するこ とができるために，術後の脊髄症状の改善も良好で あったと考える。

\section{結語}

1）脊髄症状を呈する環軸椎脱曰 43 例の手術成績 を手術方法別に，比較検註した。

2) rectangular rod を併用した後頭摜椎固定術が, 脊㕼症状の改善に最も優れていた。

3）本法は，強力な内固定力を有するため，良好な 骨療合が得られ，合併症も少なかった。

\section{文}

献

1)原田征行ほ力：環軸椎脱曰に打ける経儿的環軸椎湖 足と後方湖分の比較. 別冊整形外科，2：157-163 1982.

2) Takashi Sakou, et al. : Occipitoatlantoaxial fusion utilizing a rectangular rod. Clin. Prthop., 239 : 136144,1989

3）津川消一：経儿呐顽路環軸椎椎体間湖定術。整形外 科, $36 ： 1027-1030,1985$.
質 問

山口人学 齐能 稔

小思では骨癒合能力も高く，強固な内固定を必要と しないと考えていますが，いかがでしょうか.

\section{回 答鹿児島大学 小桜秀一郎}

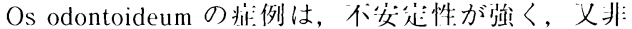
整後性であり，小思にでも後顕颈椎湖起を必要とする と考えています。

\section{質 問势赤病院 佐々木邦雄} 前方に庄迫要素の強い症例に対する現在の先生の教 窒での indication を教えて下さい。経口的除庄術の適 忍も含めて。

\section{回 答鹿児島大学 小桜秀一郎}

現在は，全ての症例に一期的に後頭澒椎固定術を 行っているが，除庄の必要なものには環椎の椎今切除 を追加している.術後脊髄症状の改善しない症例には, 経口的菌突起切除術を追加する必要があると考えてい るが，現在のところ後方からの除庄だけで良い成績を 得ています。 